\title{
The Design and Analysis of a Child Seat for a Motorcycle
}

\author{
A. Widjaya ${ }^{1, a}$, A. N. Rabbani ${ }^{2, b}$, K. R. A. N. Ningrum ${ }^{3, c}$, F. Triawan ${ }^{4, d}$ \\ 1,2,3,4 Department of Mechanical Engineering, Faculty of Engineering and Technology, Sampoerna \\ University, Jakarta 12780, Jakarta, Indonesia \\ a alvin.widjaya@my.sampoernauniversity.ac.id
}

\begin{abstract}
Abstrak.
Makalah ini membahas tentang metodologi perancangan dan analisis kursi anak sepeda motor. Setelah menyadari bahaya anak yang tidak terkendali di sepeda motor, jok ini menawarkan solusi untuk masalah tersebut. Kursi ini memiliki fitur balok geser yang memungkinkan pengguna mengakses kompartemen di bawah kursi sepeda motor dan tangki bahan bakar, tanpa perlu membongkar kursi anak. Dimensi diukur dan dipertimbangkan saat mendesain dalam aplikasi grafis. Setelah gambar perakitan selesai, kursi dianalisis untuk mengidentifikasi bagian penting dari kursi untuk memastikan tidak terjadi kegagalan. Disimpulkan bahwa desain kami dapat menahan beban statis tetapi diperkirakan akan gagal akibat kelelahan setelah $81 \times 103$ siklus dengan asumsi akselerasi 0 hingga $50 \mathrm{~km} /$ jam dalam 5 detik. Namun, karena hal itu dianggap tidak sepenuhnya dioptimalkan karena memiliki kehidupan yang terbatas, material dan dimensi diubah sehingga kehidupan yang tidak terbatas dapat diprediksi.
\end{abstract}

Kata kunci. Kursi Anak, Desain, Analisis Stres, Analisis Kelelahan.

\begin{abstract}
.
This paper discusses the methodology of design and analysis of a child seat for motorcycles. After realizing the dangers of an unrestrained child in motorcycles, this seat offers a solution to the problem. The seat features sliding beams that allow the user to access the under-seat compartment of the motorcycle and the fuel tank, without requiring any disassembly of the child seat. The dimensions are measured and considered when designing in a graphical application. Once the assembly drawing is completed, the seat is analyzed to identify critical parts of the seat to ensure failure does not occur. It is concluded that our design can withstand static loading but is predicted to fail due to fatigue after $81 \times 10^{3}$ cycles under the assumption of accelerating from 0 to $50 \mathrm{~km} / \mathrm{h}$ in 5 seconds. However, since that is not deemed to be fully optimized due to having a finite life, the material and dimensions are changed so that an infinite life can be predicted.
\end{abstract}

Keywords: Child Seat, Design, Stress Analysis, Fatigue Analysis.

\section{Introduction}

Reported by Jakarta Globe, around 2016 in Jakarta there were 6300 road accidents recorded and 591 of them are fatal [1]. Besides, a study conducted by researchers from the University of Indonesia concluded that out of the 30000 fatalities recorded nationwide, $12 \%$ of the deaths are aged 15 years and below, due to the negligence and lack of safety induction to road safety [2]. According to a report conducted by the World Health Organization (WHO), traffic injuries are the primary cause of death for children and people aged between 5 and 29 [3].

However, according to the annual report on road safety conducted in 2015 by WHO, a major proportion of fatalities due to road accidents in South East Asia is from people who use motorcycles or three-wheelers [4]. Compared to other regions, one possible reason why South East Asia has more deaths involving a motorcycle is due to the more numbers of motorcycles than other vehicles in the region. For instance, Indonesians had always preferred using motorcycles due to their smaller profile providing access to narrow roads and the ability to cut through traffic. Moreover, child restraints for 
motorcycles seem to be left unintroduced despite there are plenty of child restraints available in the market for cars. Hence, paying attention to the child restraint for motorcycle passengers is a viable solution to reduce the number of injuries due to accidents involving motorcycles.

In recent years, considerable attention has been devoted to the motorcycle accidents that can be experienced by toddlers to form child restraints and reduce the number of fatalities as WHO recommendation, referring to the report that child passengers are unrestrained and more likely to be killed in a traffic accident [5]. Besides creating restrain, the child safety seat has additional advantages over restraining or holding the baby or toddler, a simple, sleek and practical design that does not require the passenger to take off the seat to fill the fuel, securing the baby with a 5-point harness seat belt, and long-life seat design. These advantages of child seats, especially the feature, make the child safety seat product attract many motorcycles passengers' interest.

A literature survey shows that an attempt on a child seat has been conducted by many researchers with comprehensive ideas. The process also improves the properties of the part and the design. Safety factors are probably the most important aspects of assessing integrity because of their direct influence on performance. Moreover, safety is significantly affected by the working stress towards the structure which can lead to premature failure of a component.

This paper studies the methodology of designing a safety child seat that is specified for the Honda Motorcycle by using a slider. The aim is to develop a practical, strong, and safe seat. The design was developed through SOLIDWORKS and supported by several analyses such as stress, static, and fatigue analysis. The result of safety child seat design was investigated using static analysis and fatigue analysis.

\section{Problem Definition}

The development of child seats applies some boundary conditions. The limitation specifically focuses on its dimension, weight, and magnification:

- The child-seat is specifically designed for the type of scooters such as Honda Beat or Honda Vario.

- The range of the mass of the passenger is $0-18.5 \mathrm{~kg}$.

The synthesis was done by determining the features of the design and choosing the components of the seat, such as frame, slider, bolt, and its mechanism which is sliding, based on its corresponding dimension and material. In the synthesis process, the design of the child seat should meet the target and does not exceed the boundary condition. Based on the conditions above, the design process of creating a child seat was carried out using the engineering design process as shown in Figure 1.

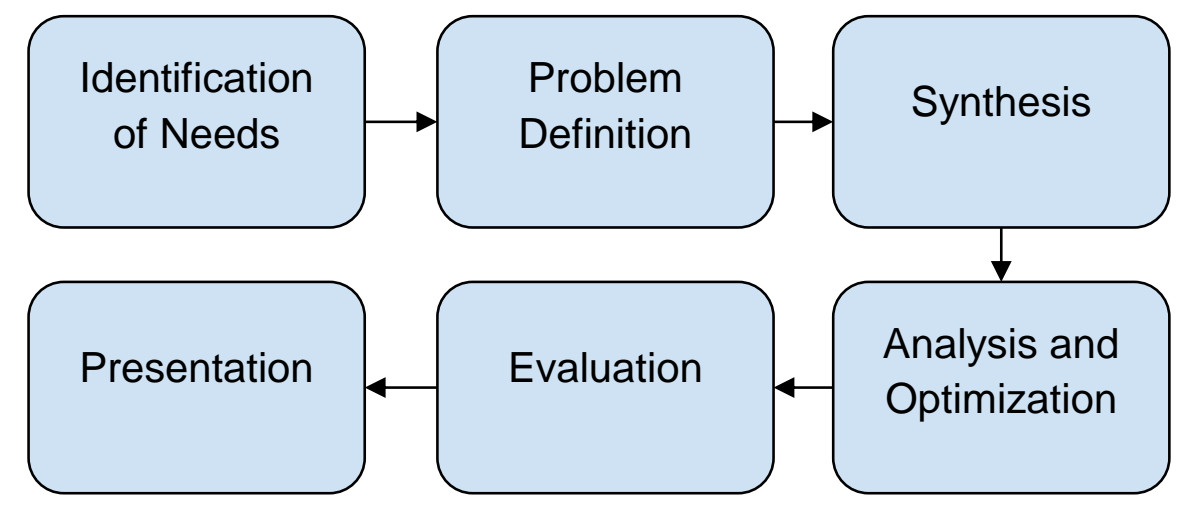

Figure 1. Design Procedure of Child Seat 


\section{Design Concept}

A common child seat usually found in Indonesia is front-mounted and made from wood such as rattan. Due to the position of the child seat that possibly interrupts the driver's view, the proposed child seat design is rear mounted, and features a sliding mechanism that allows the seat to be retracted for the motorcycle to refuel or accessing the storage compartment easily. The weight that is used in this study is the average weight of a 5-year-old, therefore the child seat could hold weight up to 18.5 $\mathrm{kg}$.

\section{Synthesis}

The synthesis process started by creating a sketch of the child seat. Recalling from the design concept, the focus for the child seat design is safety. To satisfy the safety requirement, there are several ideas proposed such as,

- Child seat design for scooter motorcycles equipped with a hinge which could rotate the seat by a 90-degree angle, so the driver could open the under-seat compartment easily without detaching the entire structure.

- The second reference figure $2 \mathrm{~b}$ is a child seat designed for snowmobile but not limited to other applications. Here the child seat is equipped with a 5-point harness to secure the child and a headcover to protect from the debris outside. Combining the idea from those two references, the design concept for the proposed child seat is shown in Figure 2 below. As its depicted in Figure 2.a is a condition when the seat in an unextend position means the driver is in driving condition. Figure 2.b is a condition when the seat is in an extended position where the driving is most likely while filling up the fuel.

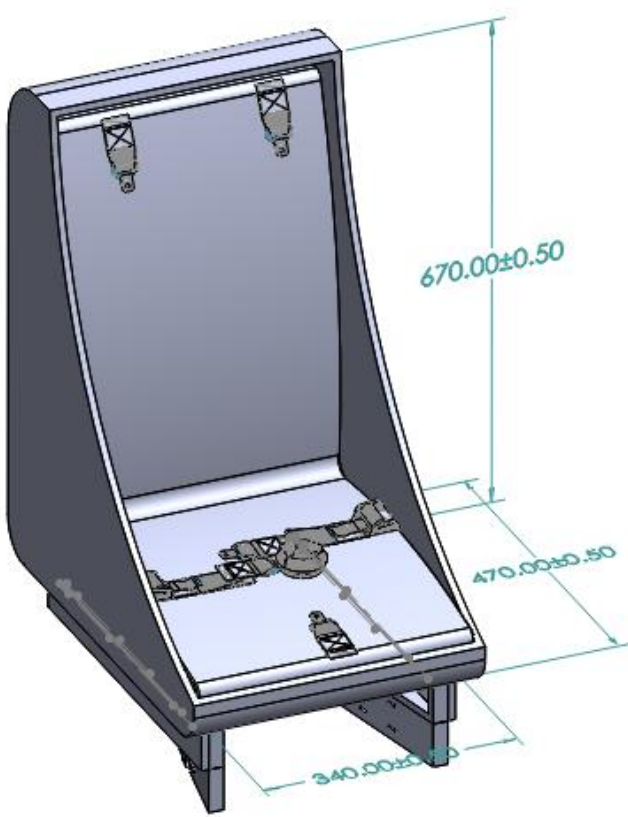

a

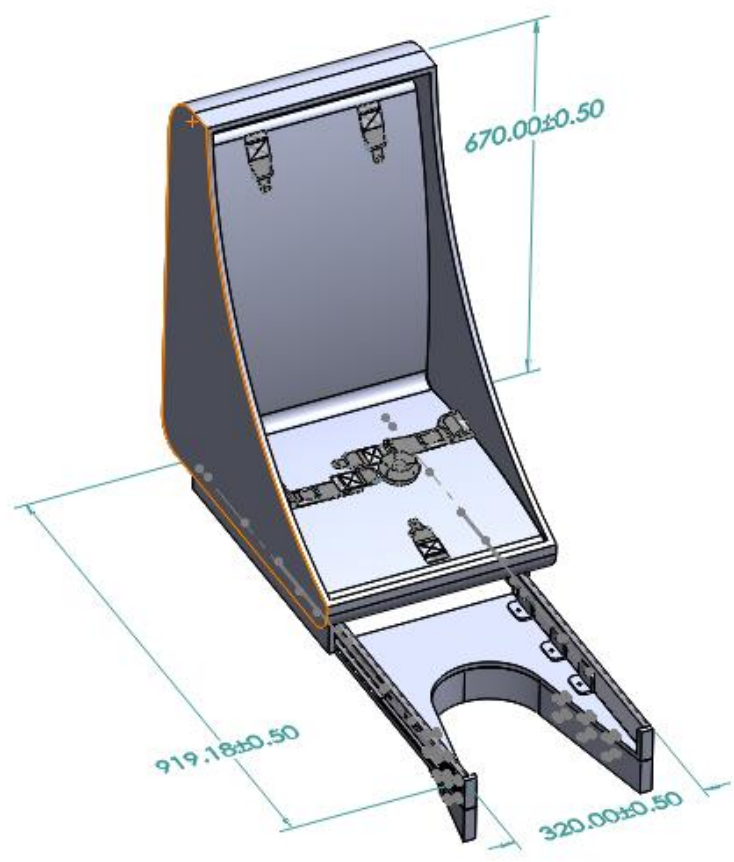

b

Figure 2. Child Seat Concept Design (a) Retracted Position (b) Extended Position (units in millimeter) 
The final design of the seat has dimensions of 470mm x 340mm x 670mm. This dimension was adjusted with the typical ones but does not exceed the size of the motorcycle itself. Below are some short explanations about each component of the child seat.

\section{- Seat and Shell}

The seat used in this design is made based on the size of an average 5-year-old child, therefore the whole body of the child could be protected. It is also equipped with a 5-point harness to securely fasten the body of the child. The seat is designed to be covered by Stainless steel shell which is expected to protect the child from the side.

\section{- Telescopic Slider}

Telescopic Slider, as shown in Figure 3, is used instead of a hinge. The reason for choosing this mechanism is to create more space while the driver wants to open the under-seat compartment. It could also be more efficient especially when the driver wants to fill the fuel while carrying their child. This telescopic slider is adapted from a common slider type of Thomas Regout Rolled Steel Slider [6]. The final design uses 1141 Steel for its outermost and middle part of the slider, whereas the innermost part uses a 4140 Steel.

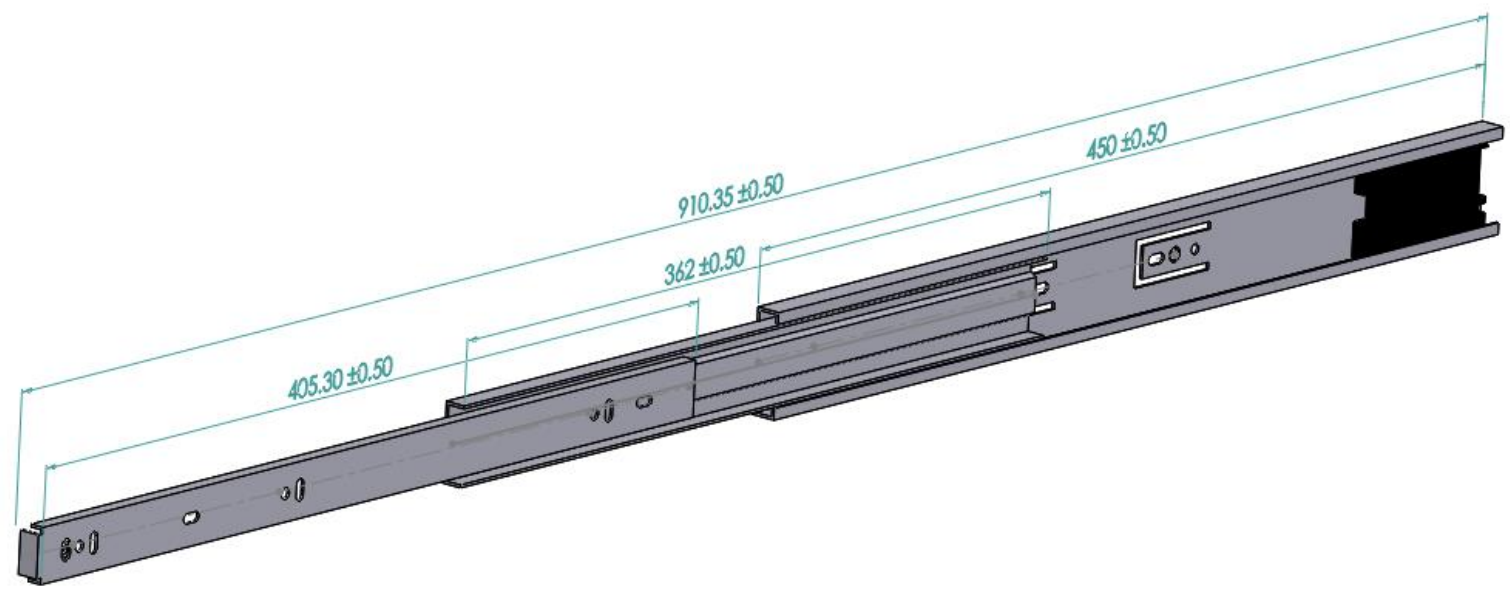

Figure 3. Telescopic Slider (units in millimeter)

\section{- Base Structure}

Figure 4 shows the structure which is the main component that supports the whole structure of the child seat. This component is connected to the motorcycle by using a clamp and $U$ beam that sits on the rear handrail of the motorcycle. On the top of the U-beam, there is a flat plate which supports the telescopic slider. This part is entirely made by AISI 1141 Steel. 


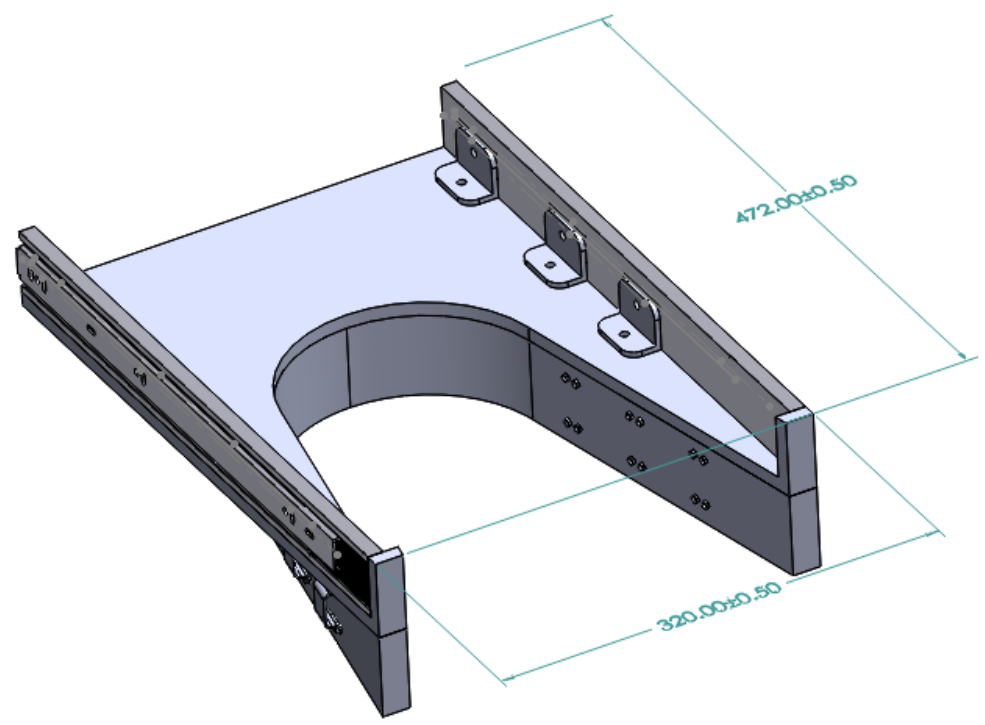

Figure 4. Base Structure (units in millimeter)

The design process undergoes several completions in terms of appearance and strength. During the process, the calculations were performed giving two options which are to replace the dimension of the slider or substitute the material. However, since the telescopic slider has a definite standard used universally so there is not much that can be done in terms of replacing the dimensions. As the only option left, the materials used are Carbon Steel AISI 1141 and AISI 4140. Accessed from the Appendix table of Shigley's Mechanical Engineering Design $10^{\text {th }}$ edition, the value of its ultimate tensile strength and tensile yield strength is adequate [7]. The mechanical properties were summarized in Table 1 below.

Table. 1. Mechanical Properties of Carbon Steel AISI 1141 and AISI 4140 [7]

\begin{tabular}{|l|c|c|}
\hline \multicolumn{1}{|c|}{ Mechanical Properties } & AISI 1141 & AISI 4140 \\
\hline Hardness, Brinell & 415 & 510 \\
\hline Tensile Strength, Ultimate & $1460 \mathrm{MPa}(212 \mathrm{kpsi})$ & $1770 \mathrm{MPa}(257 \mathrm{kpsi})$ \\
\hline Tensile Strength, Yield & $1280 \mathrm{MPa}(186 \mathrm{kpsi})$ & $1640 \mathrm{MPa}(238 \mathrm{kpsi})$ \\
\hline & & $8 \%$ \\
\hline Elongation at Break & $9 \%$ & $38 \%$ \\
\hline Reduction in Area & $32 \%$ & \\
\hline
\end{tabular}




\begin{tabular}{|l|c|c|}
\hline Modulus of Elasticity & $190-210 \mathrm{GPa}$ & $190-210 \mathrm{GPa}$ \\
\hline Poisson's ratio & $0.27-0.30$ & $0.27-0.30$ \\
\hline Temperature & $315^{\circ} \mathrm{C}$ & $205^{\circ} \mathrm{C}$ \\
\hline
\end{tabular}

\section{Analysis}

First, some assumptions were generated. The motorcycle accelerated to $50 \mathrm{~km} / \mathrm{h}$ from rest in 5 seconds and held to be constant, while the slider was left extended. The acceleration will cause an inertial force onto the seat, and when that force is translated into the slider beam, it will cause a counter-clockwise moment. Hence, it was analyzed this way because if the seat is able to withstand the added moment and inertial force, there is a much higher chance that it will not fail when stowed, in the case when the driver forgets to stow the slider when moving. However, it can be noted that accelerating at its stowed position could create a moment as well, but smaller compared to when extended. The acceleration can be found by Equation 1 .

$a=\frac{v_{f}-v_{i}}{t}$

Where $v_{f}$ is the final velocity in $\mathrm{m} / \mathrm{s}, v_{i}$ is the initial velocity $\mathrm{m} / \mathrm{s}$, and $t$ is the time taken in $\mathrm{s}$. After converting the assumed final velocity to $\mathrm{m} / \mathrm{s}$, the acceleration was found to be $a=2.78 \mathrm{~m} / \mathrm{s}$. According to the manufacturer of the motorcycle, it weighs $109 \mathrm{~kg}$ [8]. If the child weighs $18.5 \mathrm{~kg}$, as that is the average weight of a 5-year-old boy [9], and that according to the graphical application, the seat weighs about $31.36 \mathrm{~kg}$. Therefore, after summing the mass and using the calculated acceleration, the inertial force exerted onto the seat was found to be $F=282 \mathrm{~N}$.

There are two sliders, one on each side, of the seat. It was assumed that the force is distributed equally on both sides, and the weight of the child is equally distributed across the seat. Hence, the resulting Free Body Diagrams (FBD) are shown below in Figures 6, 7, and 8, in which all dimensions are in $\mathrm{mm}$.

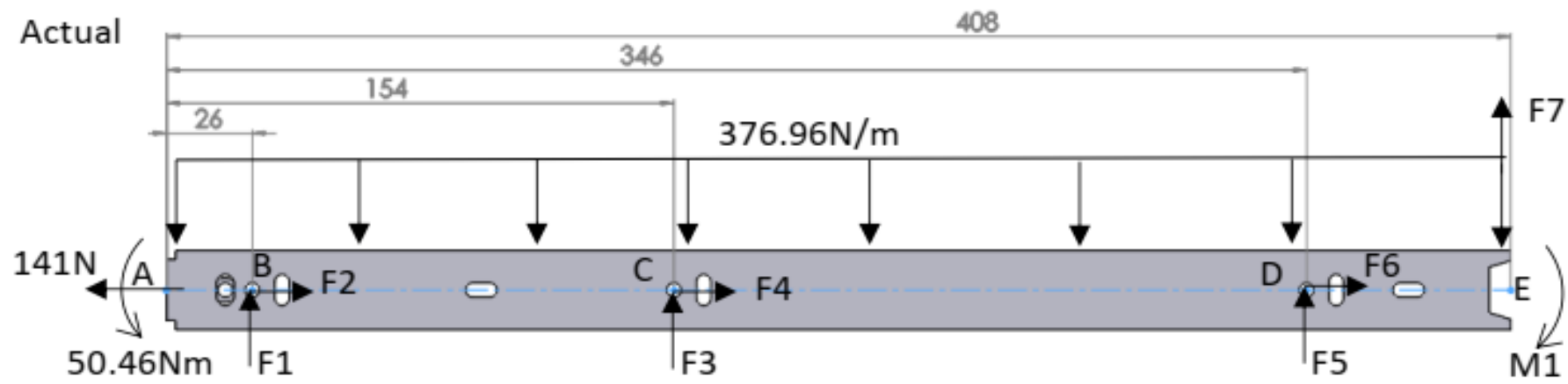

Figure 6. The Actual FBD of the Outer Slider. 


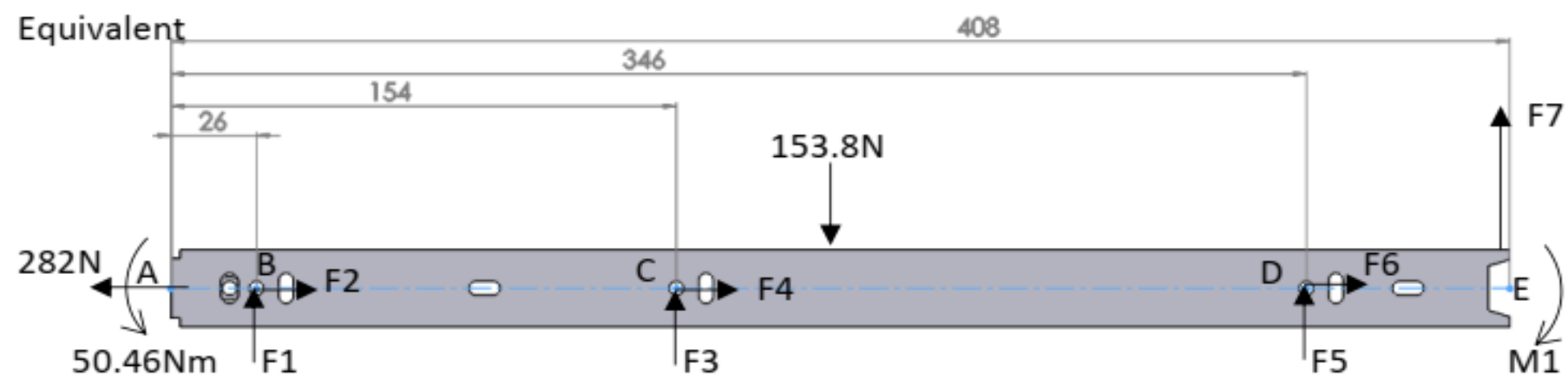

Figure 7. The Equivalent FBD of the Outer Slider.

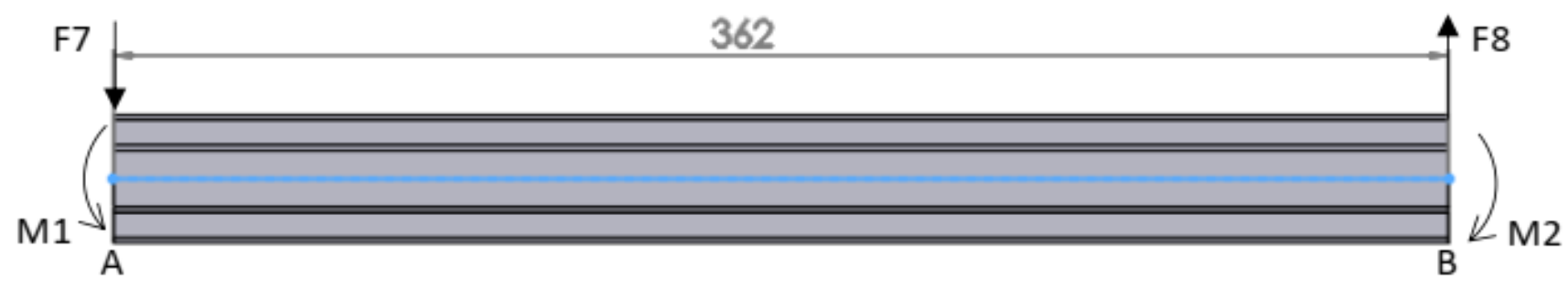

Figure 8. The FBD of the Middle Slider.

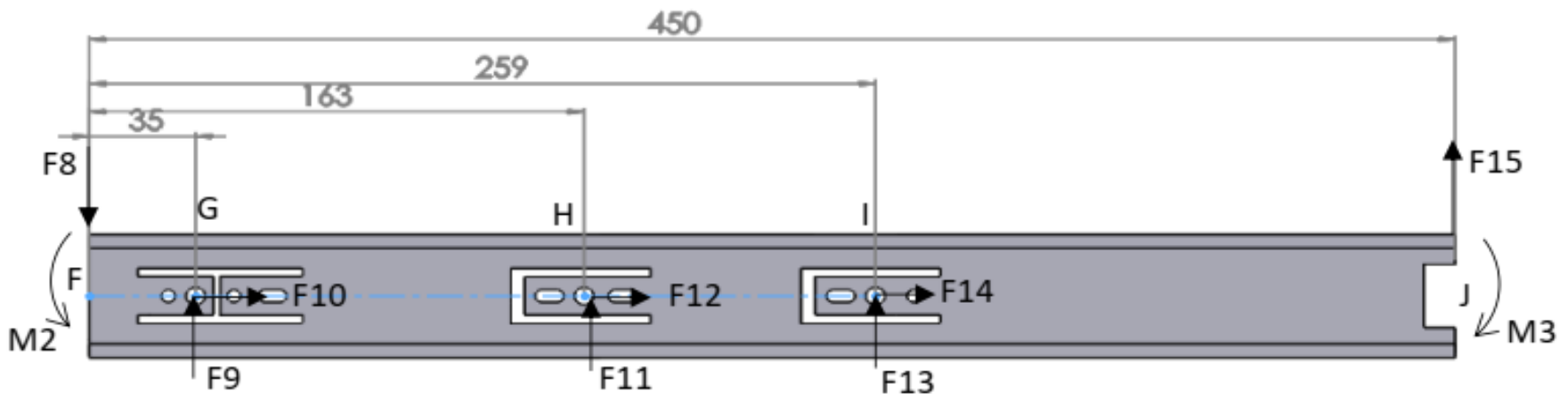

Figure 9. The FBD of the Inner Slider.

The unknown forces and moments can be found using the equilibrium conditions. After solving for the unknowns, the Shear Force Diagrams (SFD) and the Bending Moment Diagrams (BMD) can be drawn as the shown in Figures 10, 11, and 12.
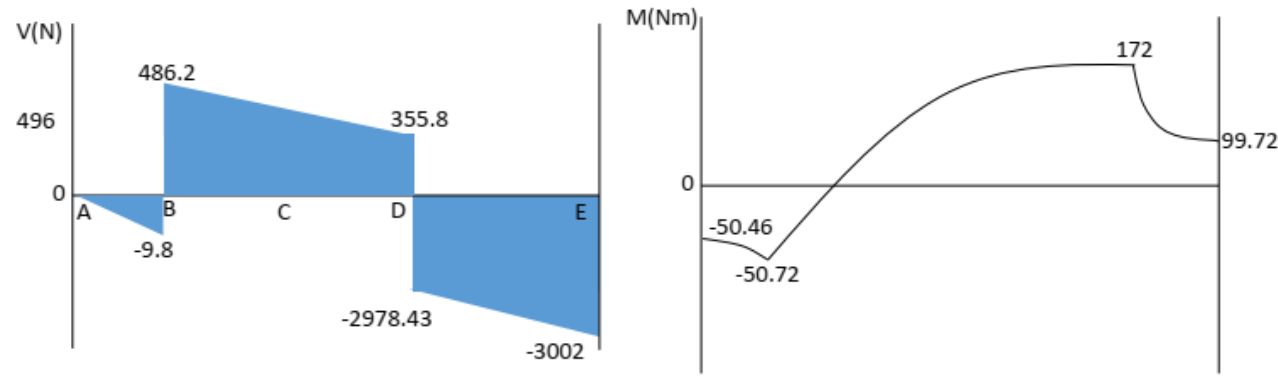

Figure 10. SFD (left) and BMD (right) of the Outer Beam. 


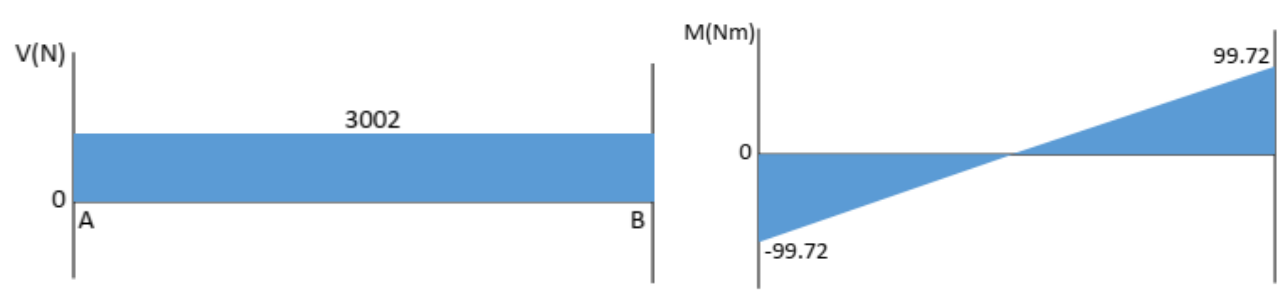

Figure 11.SFD (left) and BMD (right) of the Middle Beam.

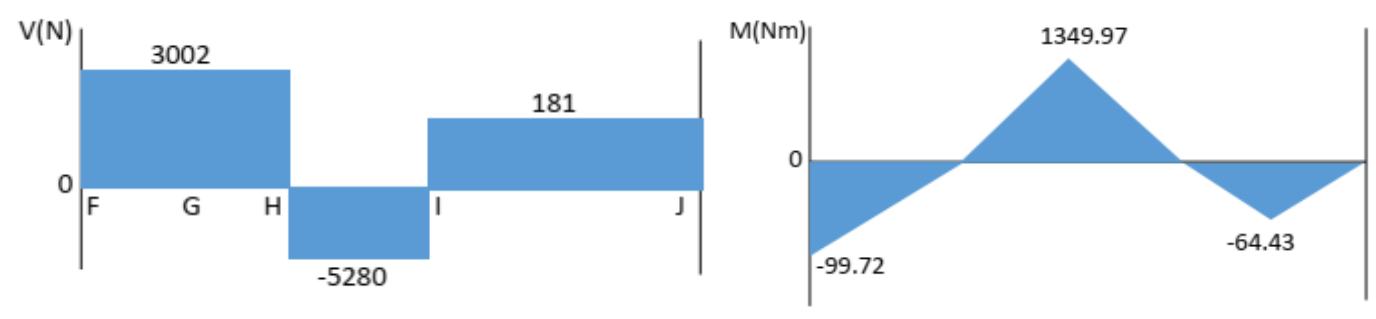

Figure 12. SFD (left) and BMD (right) of the Inner Beam.

Hence, it can be found that the critical locations are located at point $\mathrm{D}$ in the outer slider, point $\mathrm{B}$ in the middle slider, and point $\mathrm{I}$ in the inner slider. Normal stress, $\sigma$, and shear stress, $\tau$, can be calculated using Equations 2 and 3.

$\sigma=\frac{M c}{I}$

$\tau=\frac{T c}{J}$

where $M$ is the moment, $T$ is the torque, $c$ is the distance from the end to the neutral axis, $I$ is the second moment of inertia, and $J$ is the first moment of inertia.

Then, the equation for principal stresses was calculated by Equation 4 .

$\sigma_{1,2}=\frac{\sigma_{A}+\sigma_{B}}{2} \pm \sqrt{\left(\frac{\sigma_{A}-\sigma_{B}}{2}\right) \tau^{2}+\tau^{2}}$

Where $\sigma_{1,2}$ are the principal stresses, $\sigma_{A}$ and $\sigma_{B}$ are the applied normal stresses and $\tau$ is the shear stress.

After solving for the principal stress, the higher value was taken and was compared to the yield strength of the steel, the ratio was then taken as the safety factor.

The fatigue analysis started with identifying the endurance strength, $S_{e}$, which can be found by Equation 5,

$S_{e}=k_{a} k_{b} k_{c} k_{d} k_{e} k_{f} S_{e}{ }^{\prime}$

Where $S_{e}$ is the endurance strength, $k$ is the Marin modification factors due to surface finish, size, loading condition, temperature, reliability, and other external factors that may contribute to fatigue failure, and $S_{e}{ }^{\prime}$ is the ideal endurance strength.

Then, the fatigue stress concentration factor, $K_{f}$, can be found by Equation 6,

$K_{f}\left(1+\sqrt{\frac{a}{r}}\right)=\left(1+\sqrt{\frac{a}{r}}\right)+\left(K_{T}-1\right)$. 
Where $K_{f}$ is the fatigue factor, $K_{T}$ is the stress concentration factor, $\sqrt{a}$ is the Neuber constant, and $r$ is the notch size. However, the value of $K_{T}$ can be determined by using the data from Santa Clara University [10]. In this case, since the dimension of the fillet is $1 \mathrm{~mm}$ in all parts of the slider, the value of $K_{T}$ was then estimated to be about 1.5.

Afterward, the reversed stress, $\sigma_{\text {rev }}$, can be found using the Modified Goodman Criterion, denoted by Equation 7,

$\sigma_{a}=\sigma_{r e v .}\left(1-\frac{\sigma_{m}}{s_{u t}}\right)$

Where $\sigma_{a}$ is the amplitude stress, $\sigma_{m}$ is the midrange stress, and $S_{u t}$ is the ultimate tensile strength. To calculate $\sigma_{a}$ and $\sigma_{m}$, a separate static analysis was made without the inclusion of the inertial force. Since the assumption made in the fatigue analysis was the repeated acceleration motion, the stress found in this case was the minimum stress, $\sigma_{\text {min. }}$, while the stress found in the previous stress analysis was taken to be $\sigma_{\max }$. Thus, to obtain $\sigma_{a}$ and $\sigma_{m}$, Equations 8 and 9 are used,

$\sigma_{m}=\frac{\sigma_{\min .}+\sigma_{\max }}{2}$

$\sigma_{a}=\left|\frac{\sigma_{\max }-\sigma_{\min }}{2}\right|$

Combining the values found in Equations (5), (6), and (7), the fatigue safety factor can be calculated by Equation 10,

$n_{f}=\frac{s_{e}}{\sigma_{r e v .} K_{f}}$.

If $n_{f}$ is more than 1 , then infinite life is predicted. However, if $n_{f}$ is less than 1 , then finite life is predicted. In the case when finite life is predicted, the number of cycle loads, $N$, can be determined by Equation 11,

$N=\left(\frac{\sigma_{r e v}}{a}\right)^{1 / b}$.

\section{Discussion}

For the outer slider, equilibrium equations are applied to find the unknown forces and moments as in the below:

$-141+F_{2}+F_{4}+F_{6}=0$

It is assumed that the horizontal forces exerted in the bolts are equally distributed, hence solving equation (14) yields,

$F_{2}=F_{4}=F_{6}=\frac{141}{3}=47 \mathrm{~N}$

Then the sum of vertical forces is equal to zero.

$\sum F_{z}=0$

$F_{1}+F_{3}+F_{5}+F_{7}=153.8 \mathrm{~N}$

Then the sum of moments at any point is equal to zero.

$\sum M_{B}=0$ 
$128 F_{3}+320 F_{5}+382 F_{7}-M_{1}=-50460+27376.4$

$\sum M_{C}=0$

$-128 F_{1}+192 F_{5}+254 F_{7}-M_{1}=-50460+7640$

$\sum M_{D}=0$

$-320 F_{1}-192 F_{3}+62 F_{7}-M_{1}=-50460-21834.6$

$\sum M_{E}=0$

$-382 F_{1}-254 F_{3}-62 F_{5}-M_{1}=-50460-31375.2$

Solving equations (16) to (20) numerically gives the values for the unknowns $F_{1}, F_{3}, F_{5}, F_{7}$ and $M_{1}$.

$F_{1}=496 \mathrm{~N}$

$F_{3}=0$

$F_{5}=-3344 \mathrm{~N}$

$F_{7}=3002 \mathrm{~N}$

$M_{1}=99.72 \mathrm{Nm}$

From the values taken from equations (19) to (23), the Shear Force Diagram (SFD) and the Bending Moment Diagram (BMD) can be constructed and are shown in figure $\mathrm{x}$ and $\mathrm{x}$.

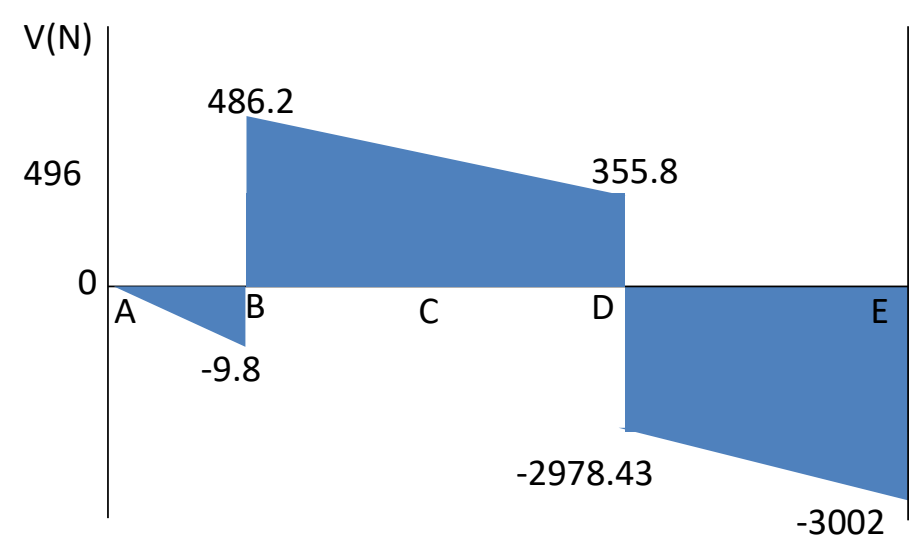

Figure 13. SFD of the Outer Slider.

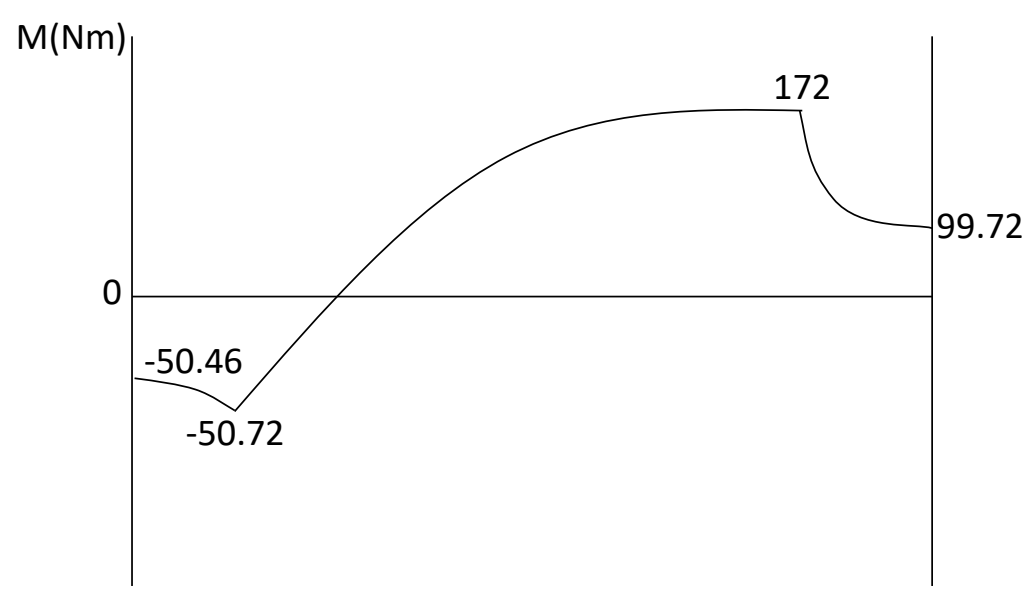

Figure 14. BMD of the Outer Slider. 
Hence, it can be concluded that the critical part of this beam is at point D. Therefore, the normal forces and shearing forces at that point is calculated by using equations (2) and (3).

$\sigma_{z}=\frac{M c}{I}=\frac{(172)\left(12.2 \times 10^{-3}\right)}{\left(6288.28 \times 10^{-12}\right)}=333.7 \mathrm{MPa}$

$\sigma_{x}=\frac{47}{\pi\left(5 \times 10^{-3}\right)\left(1.3 \times 10^{-3}\right)}=2.3 \mathrm{MPa}$

$\tau_{x y}=\frac{V Q}{I t}=\frac{(3002)\left[(6.6 \times 1.3)(10.4) \times 10^{-9}\right]}{\left(6288.28 \times 10^{-12}\right)\left(6.6 \times 10^{-3}\right)}=6.76 \mathrm{MPa}$

Therefore, the principal stress can be found using Equation 4 and the values obtained from the values taken from equations (24) to (26).

$\sigma_{1,2}=\frac{333.7+2.3}{2} \pm \sqrt{\left(\frac{333.7+2.3}{2}\right)^{2}+6.76^{2}}=\left\{\begin{array}{c}336.13 \mathrm{MPa} \\ -0.136 \mathrm{MPa}\end{array}\right\}$

Hence, it can be concluded from the principal stress that the maximum stress applied is $336.13 \mathrm{MPa}$. By using this value and the yield strength of AISI 1141 Steel from table 1 gives the safety factor.

$n=\frac{1280}{336.13}=3.8$

In conclusion, the part is deemed safe under static loading, and so fatigue analysis is conducted next.

Since that the ultimate tensile strength of AISI 1141 Steel is greater than $1400 \mathrm{MPa}$, therefore the ideal endurance strength, $S_{e}{ }^{\prime}$, is $700 \mathrm{MPa}$. The surface of the material is machined, the values of $a$ and $b$ are 4.51 and -0.265 respectively [7]. Then, the surface factor can be found by Equation 29:

$k_{a}=a\left(S_{u t}\right)^{b}$

So, the surface factor can be found as:

$4.51(1460)^{-0.265}=0.654$

Then, the size factor for the slider of this shape can be found by using equations (33) to (35).

$A_{0.95 \sigma}=0.05 a b$

$d_{c}=\sqrt{13.08 A_{0.95 \sigma}}$

$k_{b}=1.24\left(d_{c}\right)^{-0.107}$

Hence, the size factor can be obtained.

$A_{0.95 \sigma}=(0.05)(6.6)(24.4)=8 \mathrm{~mm}$

$d_{c}=\sqrt{13.08(8)}=10.23 \mathrm{~mm}$

$k_{b}=1.24(10.23)^{-0.107}=0.967$

Assuming that the rest of the Marin factors are 1, the endurance strength can be found by using equation (7).

$S_{e}=0.934 \times 0.967 \times 1 \times 1 \times 1 \times 1 \times 700=442.64 \mathrm{MPa}$

The Neuber constant can be found by Equation 36 .

$\sqrt{a}=0.264-3.08 \times 10^{-3}\left(S_{u t}\right)+1.51 \times 10^{-5}\left(S_{u t}^{2}\right)-2.67 \times 10^{-8}\left(S_{u t}^{3}\right)$ 
Where the ultimate strength is in kpsi. Therefore, the value of the Neuber constant of AISI 1141 Steel can be obtained.

$$
\begin{aligned}
\sqrt{a} & =0.264-3.08 \times 10^{-3}(212)+1.51 \times 10^{-5}\left(212^{2}\right)-2.67 \times 10^{-8}\left(212^{3}\right) \\
& =0.0353
\end{aligned}
$$

Hence, by Equation 6, the fatigue stress concentration factor can be found.

$K_{f}=1+\frac{1.5-1}{1+\frac{0.0353}{\sqrt{1}}}=1.483$

After finding the endurance strength and fatigue factor, the last remaining variable to be found is the reversed stress. After repeating the calculations from equations (14) to (27) without the inertial force and moment due to inertia, the minimum stress is found as $123.5 \mathrm{MPa}$. Therefore, the midrange and alternating stress can be found using Equations 8 and 9.

$\sigma_{m}=\frac{336.13+123.5}{2}=229.82 \mathrm{MPa}$

$\sigma_{a}=\left|\frac{336.13-123.5}{2}\right|=106.32 \mathrm{MPa}$

Therefore, the reversed stress can be found by Equation 7.

$\sigma_{\text {rev. }}=\frac{\sigma_{a}}{1-\frac{\sigma_{m}}{s_{u t}}}=\frac{106.32}{1-\frac{229.82}{1460}}=126.18$

Hence, the fatigue safety factor can be calculated using Equation 10.

$n_{f}=\frac{442.64}{126.18 \times 1.483}=2.36$

Since the value of $n_{f}$ is bigger than 1 , it can be concluded that the outer slider has an infinite life. By the same calculation and analysis for other parts, the value of safety factor for static loading is 9.1 and 1.74; while the value of fatigue safety factor, $n_{f}$, are 5.65 and 0.86 for the middle and inner slider, respectively. Since the value of $n_{f}$ for the inner slider is less than one, it does not have an infinite life. By Equation 11, the number of cycles before failure is $81 \times 10^{3}$ cycles. So, the design has a room for improvement. By changing the material of the inner slider from 1141 Steel to 4140 Steel, with a ground surface finish, instead of a machined surface finish, allows a larger value of $k_{a}$. Hence, the value for $\sigma_{r e v}$. can decrease, while the value of $S_{e}$ can increase, giving an overall larger value of $n_{f}$. In the end, the value of $n_{f}$ for the inner slider is 1.29 , thus predicting infinite life as well.

With the dimensions of $470 \mathrm{~mm} \times 340 \mathrm{~mm} \times 670 \mathrm{~mm}$, it is ensured that the seat is comfortable for the passenger, then the shell will ensure that the child is protected inside and prevent the child from reaching their limbs out too far. However, since this seat is not equipped with a cover to protect the head from external debris, or to protect the head when toppled during an accident, additional protection, such as a helmet, is recommended. In addition, a comprehensive failure analysis using numerical simulation as well as vibration mode characteristics will be done in the future work .

\section{Conclusion}

The seat is offered to be a possible solution to a problem relating to road safety. Thus, the methodology of designing and its reiteration process are made. The seat fitted at the rear has dimensions of $470 \mathrm{~mm} \times 340 \mathrm{~mm} \times 670 \mathrm{~mm}$ which can be adjusted with the size of the child and the size of a motorcycle. The analysis made in this paper assumed that the motorcycle accelerates to 50 $\mathrm{km} / \mathrm{h}$ from rest, while the assumption made in the fatigue analysis is repeated motion. The result of 
the first analysis concludes that the design, although safe, can be made safer. Therefore, after a further optimization by replacing the material to a stronger one, the seat can be granted an infinite life.

\section{References}

[1] Tamosee, H. and Tamosee, M. (2016). Indonesia Ranked 5th in the World for Highest Number of Road Accidents. [online] Jakarta Globe. Available at https://jakartaglobe.id/context /indonesiaranked-5th-world-highest-number-road-accidents/ [Accessed 2 Feb.2020].

[2] Pratiwi, Y. and Siahaan, F. (2017). ACCIDENT AMONG CHILDREN IN INDONESIA URBAN AREAS. [online] Semantic Scholar. Available at: https://pdfs.semanticscholar.org/752a /fe6cad4afe14b935413de92643004b8c3fcd.pdf [Accessed 2 Feb. 2020].

[3] World Health Organization. (2018). Road traffic injuries. [online] Available at:

https://www.who.int/news-room/fact-sheets/detail/road-traffic-injuries [Accessed 2 Feb. 2020].

[4] Global status report on road safety 2015. (2015). Geneva: World Health Organization.

[5] World Health Organization. (2008). World Report on Child Injury Prevention. [online] Available at:https://www.who.int/violence_injury_prevention/child/injury/world_report/Road_traffic_injuries _english.pdf [Accessed 2 Feb. 2020].

[6] Sliding Systems. [Online]. Available: https://gsfslides.com/thomasregout-rolled-steel-telescopic-slides-range/.[Accessed: 06-May-2020].

[7] R. G. Budynas, J. K. Nisbett, and J. E. Shigley, Shigley's Mechanical Engineering Design. New York: McGraw-Hill, 2016. pg 1050.

[8] "Spesifikasi, Keunggulan, Dan Harga Honda VARIO 125 ESP," Honda Astra Motor, 21-Oct2019. [Online]. Available: https://www.astramotor.co.id/spesifikasi-keunggulandan-harga-honda-vario-125-esp/.[Accessed: 30-Apr-2020].

[9] C. Boyd-Barrett and P. Young, "Average weight and growth chart for babies, toddlers, and beyond,” BabyCenter. [Online]. Available: https://www.babycenter.com/0_average-weightand-growth-chart-for-babies-toddlers-and-beyo_10357633.bc. [Accessed: 30-Apr-2020].

[10] Material properties for part design.[Online]. Available:http://www.dc.engr.scu.edu/cmdoc/ dg_doc/develop/material/property/a2200002.htm. [Accessed: 06-May-2020].

[11] Nurprasetio, I. P., Budiman, B. A., \& Triawan, F. (2017). Failure investigation of plastic shredding machine's flange coupling based on mechanical analysis. Indonesian Journal of Science and Technology, 2(2), 124-133.

[12] Ji, M., Inaba, K., \& Triawan, F. (2019). Vibration characteristics of cylindrical shells filled with fluid based on first-order shell theory. Journal of Fluids and Structures, 85, 275-291. 